\title{
THE ROYAL SOCIETY OF TASMANIA COMMEMORATES 175 YEARS OF SERVICE TO TASMANIA
}

\author{
by John K. Volkman \\ (with three plates)
}

\begin{abstract}
Volkman, J.K. 2019. (14:xii). The Royal Society of Tasmania commemorates 175 years of service to Tasmania. Papers and Proceedings of the Royal Society of Tasmania 153: 1-4. https://doi.org/10.26749/rstpp.153.1 ISSN 0080-4703. Honorary Editor, The Royal Society of Tasmania, GPO Box 1166, Hobart, Tasmania 7000, Australia (JKV). E-mail: johnkvolkman@gmail.com.
\end{abstract}

In 2018, The Royal Society of Tasmania commenced its celebration of 175 years of service to the people of Tasmania. As the culmination of these celebrations a special plaque was unveiled at the Argyle Street entrance to the Tasmanian Museum and Art Gallery on 14 October 2019 by the Society's Patron Her Excellency Professor the Honourable Kate Warner AC, Governor of Tasmania together with Professor Ross Large AO, President of The Royal Society of Tasmania and Ms Janet Carding, Director of the Tasmanian Museum and Art Gallery. Key Words: Aboriginal people, Royal Society of Tasmania, Tasmanian Museum and Art Gallery, anniversary plaque.

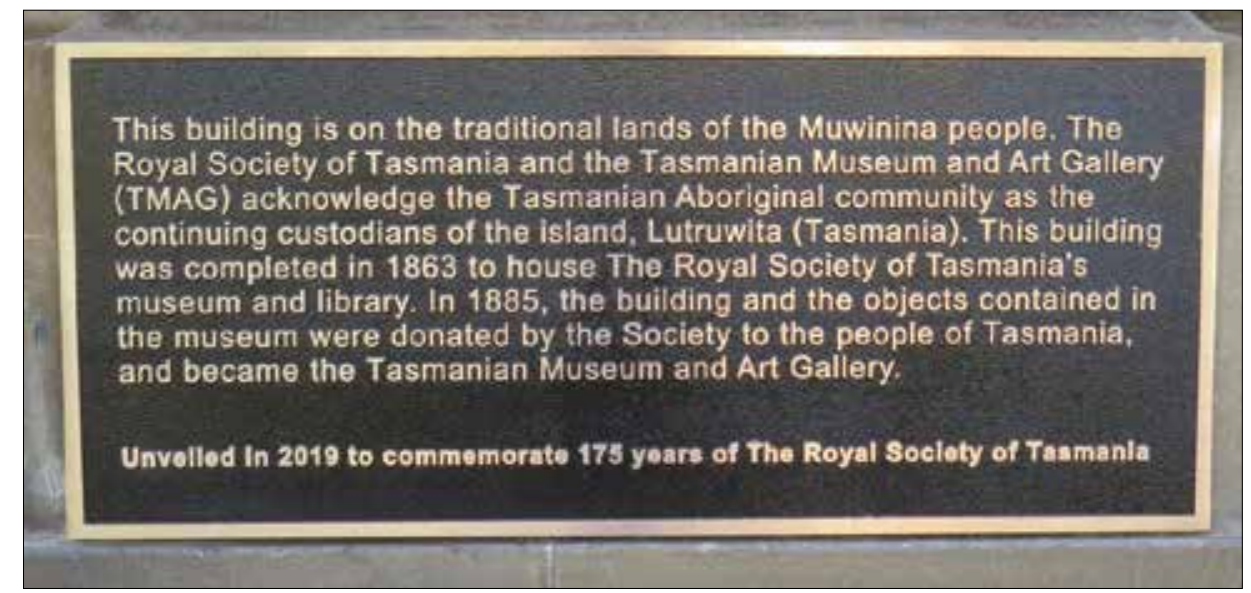

PLATE 1 - The plaque installed next to the Argyle Street entrance to TMAG (B. Pryor).

\section{INTRODUCTION}

The final official event for the year-long commemoration of the $175^{\text {th }}$ Anniversary of The Royal Society of Tasmania took place on Monday, 14 October 2019 at the Tasmanian Museum and Art Gallery (TMAG) in Hobart. It was hosted by the Director of the Tasmanian Museum and Art Gallery, Ms Janet Carding, who gave the welcome address and introduced the speakers, Professor Ross Large AO, President of The Royal Society of Tasmania and Her Excellency Professor the Honourable Kate Warner AC, Governor of Tasmania and Patron of the Society. Their speeches are given below. Following the unveiling (pls 1-3) a presentation was made to Dr Anita Hansen in recognition of her sterling work as Convener of the $175^{\text {th }}$ Anniversary Committee. A full listing of anniversary events compiled by Dr Hansen is provided following the text of the speeches.

\section{SPEECH BY THE PRESIDENT OF THE ROYAL SOCIETY OF TASMANIA, PROFESSOR ROSS LARGE AO}

Thank you, Janet.

The plaque that the Governor, our Patron, is about to unveil represents 175 years of continuous service of The Royal Society of Tasmania. The Royal Society of Tasmania (RST) has a long and proud history and was instrumental in the development of the colony of Tasmania especially in its first 100 years. This includes establishing the Royal Tasmanian Botanical Gardens (RTBG), the Tasmanian Museum and Art Gallery (TMAG), the Salmon Ponds in the Derwent Valley, the first meteorological stations, and was involved in other key issues such as the exploration of the Tasmanian landscape, promotion of the first areas for National Parks and experimentation and identification of suitable industries for Tasmania. Today the RST continues as a scientific (and historical) society with the mission of "The advancement of knowledge". 
The $175^{\text {th }}$ Anniversary year has been an excellent year for The Royal Society of Tasmania. Dr Anita Hansen (Convener) and the $175^{\text {th }}$ Anniversary Committee have worked tirelessly to produce an outstanding array of events for our $175^{\text {th }}$ celebrations.

A list of the major public events includes:

- The Dinosaur rEvolution exhibition, held jointly with TMAG which had over 60,000 visitors over $51 \frac{1}{2}$ months.

- The Dinosaur Picnic in the Park, held jointly with the Royal Tasmania Botanical Gardens which attracted over 2,000 Tasmanian families.

- The publication of two magnificent books based on the rare book archives of RST: Mapping Van Diemen's Land and the Great Beyond edited by Lynn Davies, Margaret Davies and Warren Boyles; and secondly, Poles Apart: Fascination, Fame and Folly edited by Anita Hansen and Brita Hansen.

- An anniversary play, The Laughing Gas Cure, written by Stella Kent was presented by our Northern Branch with great success.

- Two art exhibitions, one in February jointly with the Art Society of Tasmania featuring the RST art of Louisa Anne Meredith and another by TMAG in March featuring the RST artworks of Simpkinson de Wesselow.

- Finally, a scientific symposium: Dinosaurs and Evolution of Life featuring talks by dinosaur experts and palaeontologists from around Australia in March this year.
During this $175^{\text {th }}$ year, the Society also formed an Aboriginal Engagement Committee with co-chairs Dr Gregory Lehman and Professor Matt King to investigate past actions by the RST in relation to Tasmanian Aboriginal people and develop a strategy for reconciliation.

I am proud and immensely privileged to be the President of a scientific society with such a significant historical role in the development of Tasmania, but also a society made up of members - volunteers who all want to give back something to their State by way of encouraging younger Tasmanians through scholarships, lectures, symposiums, dinosaur exhibitions, art exhibitions etc. It all comes back to the advancement of knowledge for all ages. My proudest moment this $175^{\text {th }}$ year was seeing all the young children having so much fun at our dinosaur exhibition and the dinosaur picnic in the gardens. These were collaborations with TMAG and RTBG, the two organisations that the RST founded and ran for 40 years from 1843 to 1885 . I have also been incredibly proud of our RST Council and associated members who have worked tirelessly over our $175^{\text {th }}$ year, to bring such a varied and exciting program of events to the general public of Tasmania.

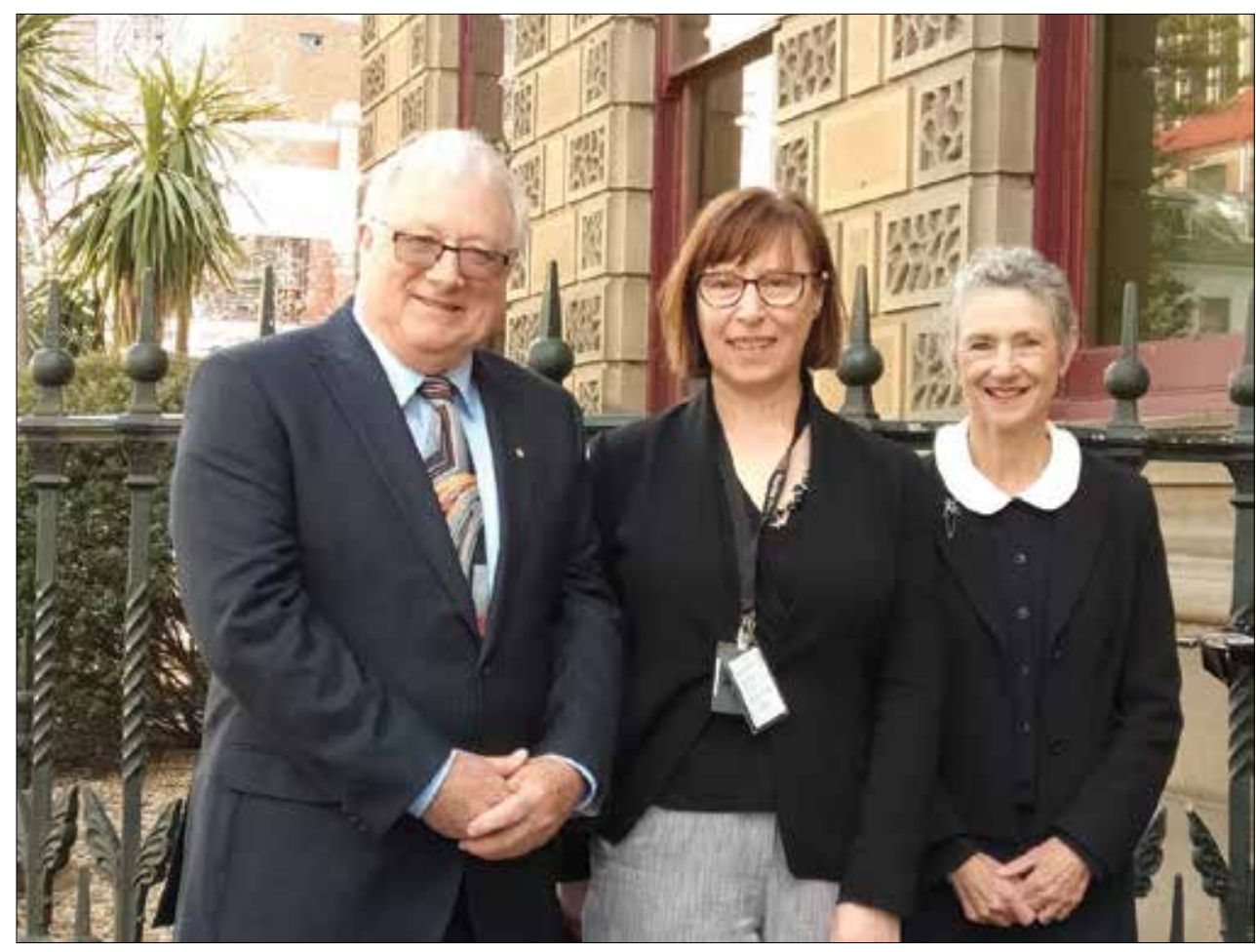

PLATE 2 - Professor Ross Large AO, President of The Royal Society of Tasmania, Ms Janet Carding, Director of the Tasmania Museum and Art Gallery and Her Excellency Professor the Honourable Kate Warner AC, Governor of Tasmania and Patron of the Society (B. Pryor). 


\section{SPEECH BY \\ HER EXCELLENCY PROFESSOR THE HONOURABLE KATE WARNER AC GOVERNOR OF TASMANIA}

Thank you, Janet.

As we have heard from Ross, The Royal Society of Tasmania's anniversary year has been well and truly celebrated and commemorated as it should be, given the Society's great age in the Australasian context, and its status as one of the oldest such societies outside the UK.

Furthermore, the Society, as the progenitor of both the Royal Tasmanian Botanical Gardens and the Tasmanian Museum and Art Gallery, lays just claim to being a preeminent Australian scientific, cultural and intellectual body. This is underscored through the Society's close association with the University of Tasmania, through its Library being housed at the University; while the Northern Branch is based at Launceston's Queen Victoria Museum and Art Gallery. Further proof of your status as a repository of science and culture lies in the Papers and Proceedings of the Royal Society of Tasmania, an amazing historical collection of scientific papers from the mid-nineteenth century to today.

And the Society's relationship with the Office of the Governor is particularly strong and enduring - albeit with a mildly controversial initiating element. Prior to your founding as the Botanical and Horticultural Society of Van Diemen's Land in 1843, by Lieutenant-Governor Sir
John Eardley-Wilmot, his predecessor Sir John Franklin had established The Tasmanian Society in 1841, which published The Tasmanian Journal of Natural Science, Agriculture [and] Statistics. Immediately following the departure of Franklin, a split occurred in that body, leading to the creation, at the behest of Eardley-Wilmot, of a new society on Saturday 14 October 1843. And the following year Eardley-Wilmot secured Queen Victoria's patronage and you became "The Royal Society of Van Diemen's Land for Horticulture, Botany and the Advancement of Science".

Meetings of the Royal Society were held in the Harrington Street Museum from 1852; and in 1861 Governor Sir Henry Fox Young, as President, laid the foundation stone of The Royal Society of Tasmania's museum and library.

Volume 2 of the Papers and Proceedings of the Royal Society of Tasmania contains two papers from W.T. Denison, who was the last Lieutenant Governor of Van Diemen's Land before it was granted self-government and became Tasmania. The first paper was titled, "On various modes of planting the potato", and the second dealt with "manures most suitable for turnips". A later Governor, Frederick Weld, was coauthor of a number of papers dealing with the introduction of salmon, related no doubt to the establishment of the Salmon Ponds, which the Royal Society was responsible for.

I will quote now the words of the plaque that is about to be unveiled:

"This building is on the traditional lands of the Muwinina people. The Royal Society of Tasmania and the Tasmanian

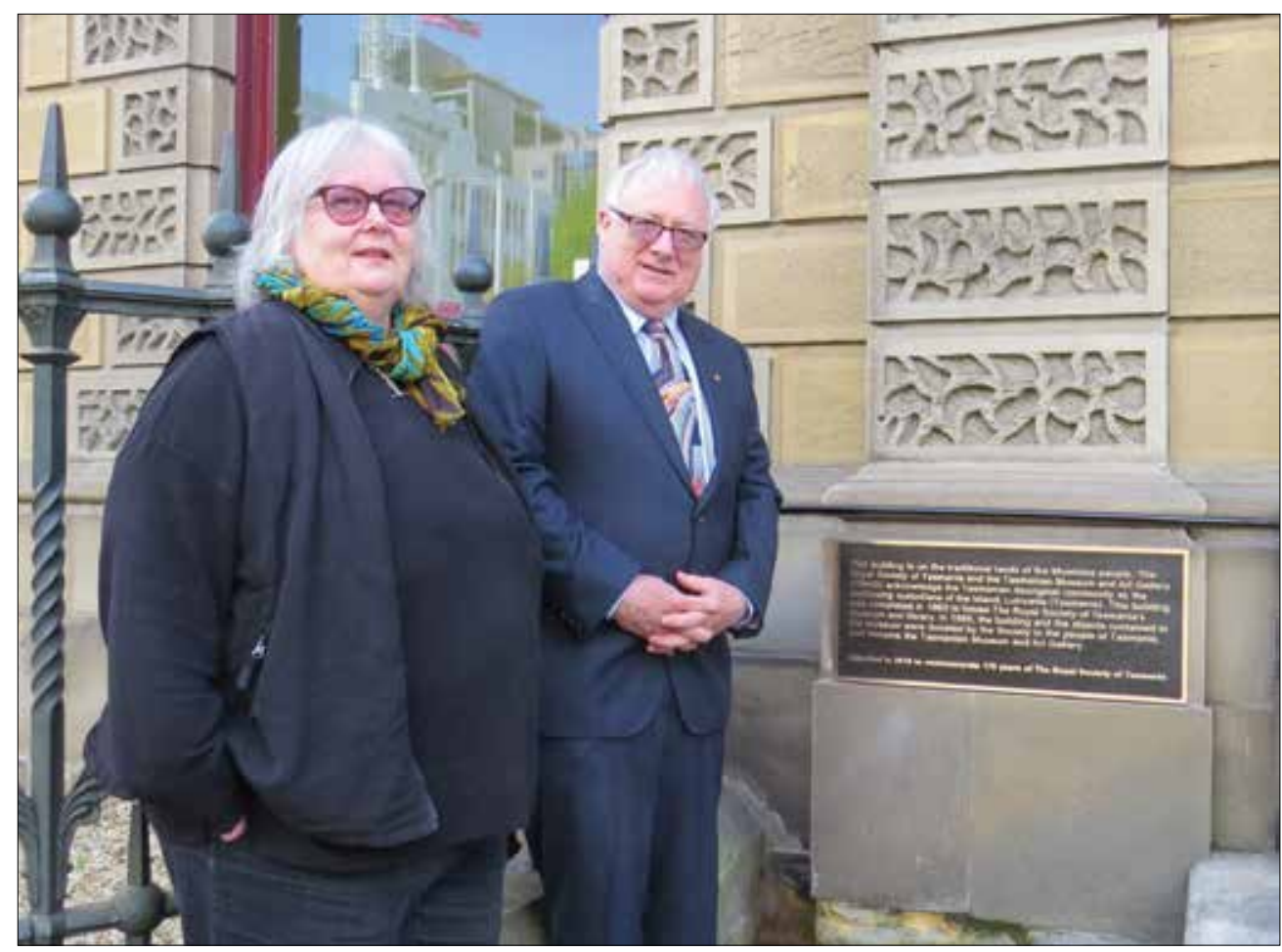

PLATE 3 - Dr Anita Hansen and Professor Ross Large AO at the plaque unveiling (B. Pryor). 
Museum and Art Gallery acknowledge the Tasmanian Aboriginal community as the continuing custodians of the island, Lutruwita (Tasmania). This building was completed in 1863 to house The Royal Society of Tasmania's museum and library. In 1885, the building and the objects contained in the museum were donated by the Society to the people of Tasmania and became the Tasmanian Museum and Art Gallery."

While it took some years for the Society to find its true home, patronage has been central to the Society's identity virtually since its founding, with Queens and Kings as Patrons and Governors as Presidents - until in 2003 the Governor of Tasmania became Patron.

I am honoured to continue in that role, and it is a great privilege for me to be able to demonstrate that by now unveiling this plaque, as a permanent marker of the great achievements past and to come of The Royal Society of Tasmania.

\section{LIST OF EVENTS CELEBRATING THE $175^{\text {TH }}$ ANNIVERSARY}

This list was compiled by Dr Anita Hansen as Convener of the $175^{\text {th }}$ Anniversary Committee which organised all of the commemorative events.

19 July 2018: Mapping Van Diemen's Land and the Great Beyond - Book launch at the Stanley Burbury Theatre, University of Tasmania, Sandy Bay campus.

30 August 2018: Royal Society of Tasmania medal presentation and lecture at Government House, Hobart.

30 September 2018: The Laughing Gas Cure - Play reading at the Queen Victoria Museum and Art Gallery, Inveresk, Launceston.

14 October 2018: Mapping Van Diemen's Land and the Great Beyond-Book launch at the Queen Victoria Museum and Art Gallery, Inveresk, Launceston.

18 October 2018; Reception to mark The Royal Society of Tasmania's $175^{\text {th }}$ Anniversary at Government House, Hobart. 6 November 2018: Poles Apart: Fascination, Fame and Folly - Book launch at the Tasmanian Museum and Art Gallery, Dunn Place, Hobart.
10 November 2018: Dinosaur Picnic at the Royal Tasmanian Botanical Gardens, Queens Domain, Hobart.

13 November 2018: Poles Apart: Fascination, Fame and Folly - Exhibition at the Morris Miller Library, University of Tasmania, Sandy Bay campus.

21 November 2018: Book stall at Fullers Book Shop Christmas sale in Hobart.

25 November 2018: Poles Apart: Fascination, Fame and Folly - Book launch at the Queen Victoria Museum and Art Gallery, Inveresk, Launceston.

6 December 2018: Launch of DINOSAUR rEVOLUTION in Hobart.

11 December 2018: Royal Society of Tasmania members sneak peek at DINOSAUR rEVOLUTION.

7 December 2018 to 5 May 2019: DINOSAUR $r E V O L U T I O N$ at the Tasmanian Museum and Art Gallery, Dunn Place, Hobart.

2-24 February 2019: Louisa Anne Meredith: A Remarkable Woman art exhibition at the Lady Franklin Gallery, Ancanthe Park, Lenah Valley, Hobart.

23-24 March 2019: Dinosaur Symposium at the Stanley Burbury Theatre, University of Tasmania, Sandy Bay campus.

21 March to 11 June 2019: Simpkinson De Wesselow art exhibition at the Tasmanian Museum and Art Gallery, Dunn Place, Hobart.

16 August 2019: Sponsorship of a talk at Beaker Street in Hobart.

3 October 2019 to 3 March 2020: Louisa Anne Meredith: A Remarkable Woman art exhibition at the East Coast Heritage Museum in Swansea.

14 October 2019: Unveiling of the $175^{\text {th }}$ anniversary plaque on the Tasmanian Museum and Art Gallery building in Hobart.

\section{ACKNOWLEDGEMENTS}

I am grateful to Professor Ross Large AO and Her Excellency Professor Kate Warner AC for making their speeches available for publication, to Bernard Pryor for photographs and to Dr Anita Hansen for the compilation of events organised by the $175^{\text {th }}$ Anniversary Committee. 